\title{
Interaction between sugarcane families and plant growth-promoting bacteria in two crop cycles
}

\section{Interação entre famílias de cana-de-açúcar e bactérias promotoras do crescimento vegetal em dois ciclos de cultivo}

\author{
Valéria Rosa Lopes ${ }^{1 *}$; João Carlos Bespalhok Filho²; Guilherme Grodzki Oliveira \\ Figueiredo $^{1}$; Ricardo Augusto de Oliveira ${ }^{2}$; Edelclaiton Daros ${ }^{2}$
}

\begin{abstract}
The response of sugarcane (Saccharum spp.) families to the inoculation with plant growth-promoting bacteria (PGPB) may show positive or negative interaction values depending on the plant genotype, allowing the selection of responsive genotypes to the association. Based on these precepts, this study aimed to evaluate the response of 27 sugarcane families treated with two PGPB-based inoculants in two sugarcane cycles: plant-cane and first ratoon. Four months after germination, 27 families from crosses between clones of sugarcane were: (T0) not inoculated; (T1) inoculated with Triazo, which consists of a mixture of the strains Abv5, Abv6, and Abv7 of Azospirillum brasilense; and (T2) inoculated with an inoculant called Mix, which contains five strains of PGPB (Gluconacetobacter diazotrophicus Pa15, Azospirillum amazonense CBAmC, Burkholderia tropica Ppe8, Herbaspirillum rubrisubalbicans $\mathrm{HCc} 103$, and Herbaspirillum seropedicae HRC54). The productivity traits evaluated were the number of stalks, average height, stalk diameter, and Brix. The correlation values between the two cycles were 0.87 for the number of stalks, 0.70 for average height, 0.48 for stalk diameter, and 0.63 for Brix. Differences were observed between treatments for average height, stalk diameter, and Brix. Differences were also observed between families for all the studied traits. Brix was the only parameter that presented a significant interaction between family and inoculant. Different responses were observed between cycles for some families, showing that other factors can also influence the association.
\end{abstract}

Key words: PGPB. Sugarcane breeding. Plant-bacteria interaction. Nitrogen-fixing bacteria.

\section{Resumo}

A resposta de famílias de cana-de-açúcar (Saccharum spp.) à inoculação com bactérias promotoras de crescimento vegetal (PGPB) pode apresentar valores positivos e negativos de interação, o que possibilita a seleção genótipos responsivos à associação. O objetivo do presente estudo foi avaliar a resposta de 27 famílias de cana-de-açúcar tratadas com dois diferentes inoculantes a base de PGPB em dois ciclos de cultivo, cana-planta e cana-soca. Famílias provenientes de cruzamentos biparentais receberam três diferentes tratamentos: (T0) não inoculadas; (T1) inoculadas com Triazo (composto pelas estirpes Abv5, Abv6 e Abv7 de Azospirillum brasilense); (T2) inoculadas com um Mix contendo cinco diferentes espécies de PGPB (Gluconacetobacter diazotrophicus Pal5, Azospirillum amazonense CBAmC, Burkholderia tropica Ppe8, Herbaspirillum rubrisubalbicans HCc103 e Herbaspirillum seropedicae HRC54). Foram avaliadas as seguintes variáveis por planta: número de colmos, altura

\footnotetext{
${ }^{1}$ Drs. em Agronomia, Universidade Federal do Paraná, UFPR, Curitiba, PR, Brasil. E-mail: agroval@yahoo.com; guigrodzki@ yahoo.fr

2 Profs. Pesquisadores, Departamento de Fitotecnia e Fitossanitarismo, UFPR, Curitiba, PR, Brasil. E-mail: bespa@ufpr.br; eddaros@ufpr.br; rico@ufpr.br

* Author for correspondence
} 
média, diâmetro médio e Brix. Os resultados mostraram que o valor de correlação entre os dois ciclos foi de $0,87,0,70,0,48$ e 0,63 , para número de colmos, altura, diâmetro e Brix, respectivamente. Houve efeito significativo do tratamento para as variáveis, altura e diâmetro médio da planta e Brix, assim como diferença entre as famílias para todas as variáveis estudadas. A variável Brix foi a única que apresentou interação significativa entre família e inoculante. Observaram-se diferentes respostas entre os ciclos para algumas famílias, mostrando que outros fatores também influenciam na associação.

Palavras-chave: PGPB. Melhoramento genético. Interação planta-bactéria. Bactérias fixadoras de nitrogênio.

\section{Introduction}

Sugarcane (Saccharum spp.) is a crop that demands a large amount of nitrogen fertilizers for its development. However, researches have shown in Brazil that sugarcane plants maintained their productivity indices without symptoms of nutritional deficiency even without nitrogen fertilization (URQUIAGA et al., 1992). Other studies have identified different genus of bacteria associated to sugarcane and responsible for the biological nitrogen fixation (BNF), standing out the genera Gluconacetobacter, Herbaspirillum, Azospirillum, Burkholderia, Beijerinckia, and Azotobacter (BALDANI; BALDANI, 2005).

In addition to BNF, other benefits have been attributed to these bacteria (BASHAN et al., 1990; VERMA et al., 2010), such as the production of plant regulators, root system proliferation, increased water and micronutrient uptake, phosphate solubilization, and nutrient mobilization. Due to these effects, these bacteria came to be called plant growth-promoting bacteria (PGPB). Recently, other mechanisms of action have been discovered and attributed to these bacteria, such as the transport of small molecules and enzymes, increased membrane proton flux activity, direct and indirect control of phytopathogens, and mitigation of environmental stresses such as saline and water stress (ARZANESH et al., 2009; BASHAN; BASHAN, 2011). These positive effects can be indirectly observed in plants by means of quantitative and/or qualitative production characteristics.

Studies with sugarcane have shown the interaction between genotype and bacteria, which would be responsible for the different results regarding the efficiency of nitrogen fixation, demonstrating the influence of plant genotype on BNF success (MUÑOZ-ROJAS; CABALLERO-MELLADO, 2003; COELHO et al., 2003; HARI; SRINIVASAN, 2005; OLIVEIRA et al., 2006). These studies led to the hypothesis that plant breeding could assist in increasing BNF efficiency. In this sense, Alcantara et al. (2009) emphasized the need to perform studies prioritizing the macrosymbiont (plant), which is essential for the success of breeding programs that aimed higher BNF results.

In Brazil, the selection of soybean cultivars in soils with low nitrogen contents, without chemical fertilization, and with the inoculation of Bradyrhizobium strains was essential to increase BNF efficiency in this species (ALVES et al., 2003). This leads us to believe that in sugarcane, the need to select also the plant genotype is even more important (MARIN et al., 1999) because the plant-bacteria interaction is associative, i.e. it is less efficient than the symbiotic, indicating that an ideal plant-bacteria combination may result in more significant gains.

In a study with 54 sugarcane families, Lopes et al. (2012) observed a significant difference in the response of families to the treatment with two inoculants composed by Azospirillum brasilense. However, these authors performed only one evaluation (plant-cane) and used an inoculant composed by facultative endophytic bacteria not specific for sugarcane. Nevertheless, these authors observed an increase in the values of traits related to plant growth promotion, as well as suggested that further studies should be carried out. 
Thus, this study aimed to evaluate the response of 27 sugarcane families treated with two different inoculants composed by plant growth-promoting bacteria regarding the quantitative traits number of stalks, average plant height, average plant diameter, and Brix in the crop cycles plant-cane and first ratoon.

\section{Materials and Methods}

The experiment was conducted from 2009 to 2012 at the Experimental Station of Paranavaí of the Federal University of Parana (UFPR), located in Paranavaí, PR, Brazil $\left(23^{\circ} 05^{\prime} \mathrm{S}, 52^{\circ} 27^{\prime} \mathrm{W}\right.$, altitude of $503 \mathrm{~m}$ ). The regional climate is classified as Cfa according to the Köppen classification system
(IAPAR, 1994). The soil of the experimental area is classified as a sandy textured Latossolo Vermelho Escuro Distrófico according to the Brazilian Soil Classification System (EMBRAPA, 1999) and as a Ferralsol (Dystric) according to FAO (2006).

Seeds (caryopsis) from 27 biparental crosses between sugarcane genotypes were used. These crosses were performed in 2009 at the Serra do Ouro Crossing Station located in Murici, AL (Table 1). The seeds were germinated in plastic trays containing the substrate Plantmax ${ }^{\circledR}$ and maintained in a greenhouse with constant irrigation. The seedlings were transplanted at 40 days after sowing to styrofoam trays with individual cells $\left(60 \mathrm{~cm}^{3}\right)$ placed under $50 \%$ shading until planting.

Table 1. List of the studied 27 sugarcane families and the cross parents.

\begin{tabular}{cccccc}
\hline Family & Cross & Family & Cross & Family & Cross \\
\hline 1 & RB99361 X RB98710 & 10 & RB971755 X RB987933 & 19 & RB975932 X RB912695 \\
2 & RB931565 X RB72454 & 11 & RB936095 X RB965920 & 20 & RB855536 X RB966924 \\
3 & RB9557 X RB946022 & 12 & SP80-185 X RB966291 & 21 & RB951541 X RB867515 \\
4 & RB965911 X RB93509 & 13 & RB965517 X LAICA01606 & 22 & RB845197 X RB931611 \\
5 & RB936109 X RB855595 & 14 & RB981801 X RB91514 & 23 & UFPR4 X RB965911 \\
6 & RB931011 X RB961003 & 15 & RB855546 X RB91514 & 24 & RB965517 X RB991555 \\
7 & RB931011 X RB9629 & 16 & RB951514 X RB845197 & 25 & RB971537 X RB991555 \\
8 & RB855036 X RB951539 & 17 & RB845197 X RB991534 & 26 & RB845210 X RB941537 \\
9 & RB966229 X RB92579 & 18 & IAC93-6033 X RB83102 & 27 & RB936001 X RB867515 \\
\hline
\end{tabular}

At four months after sowing, the plants were treated with plant growth-promoting bacteria inoculants, remaining under $50 \%$ shading for seven days and then transplanted to the field (the first stage of the sugarcane-breeding program).

One of the inoculants used was composed of three strains of $A$. brasilense and was named Triazo. This inoculant was supplied by the Department of Biochemistry and Molecular Biology of the Federal University of Paraná (UFPR). The strains Abv5, Abv6, and Abv7 were isolated from corn (HUNGRIA et al., 2010) and the inoculant was prepared according to the methodology described by
Lopes et al. (2012). The other inoculant, composed by a mixture of five PGPB species, was supplied by the National Center of Agrobiology Research of the Brazilian Agricultural Research Corporation (EMBRAPA) and was named Mix. The Mix contains the following strains: G. diazotrophicus, strain BR 11281 (PAL 5); H. seropedicae, strain BR 11335 (HRC54); H. rubrisubalbicans, strain BR 11504 (HCC103); A. amazonense, strain BR 11115 (CBAmC); and B. tropica, strain BR 11366 (Ppe 8) (OLIVEIRA et al., 2009). The Mix was prepared according to the methodology described by Oliveira et al. (2009), being used in the peat form dissolved 
in water in the plant-cane and in the liquid form in the first ratoon.

Plants from each family were subjected to one of the following treatments: no inoculation (Control, T0); inoculation with $100 \mu \mathrm{L}$ of Triazo $\left(10^{9}\right.$ bacteria $\left.\mathrm{mL}^{-1}\right)(\mathrm{T} 1)$; or inoculation with $1 \mathrm{~mL}$ of Mix $\left(10^{9}\right.$ bacteria $\left.\mathrm{mL}^{-1}\right)(\mathrm{T} 2)$. A total of $100 \mu \mathrm{L}$ or $1 \mathrm{~mL}$ of the appropriate inoculant (at the mentioned concentrations) was applied to the base of each plant with a micropipette. The largest amount of Mix (1 mL) was due to the inoculant be provided in the peat form and needed to be dissolved before the application.

The experiment had a completely randomized block design with three replications and a split-plot arrangement of treatments. Each block consisted of 27 plots and one family was planted at each plot. A plot consisted of three rows of $5 \mathrm{~m}$ long and contained 10 plants and each row was subjected to a different inoculation treatment (T0, T1 or T2). The spacing was $1.4 \mathrm{~m}$ between rows and $0.5 \mathrm{~m}$ between plants. Sugarcane plants from polycrosses were used as a side border for this area.

Planting was conducted in February 2010. Fertilization was performed in the planting furrow and each row (5 $\mathrm{m}$ long) received $540 \mathrm{~g}$ of potassium chloride and $180 \mathrm{~g}$ of simple superphosphate without adding nitrogen. Plants were maintained without irrigation, in accordance with the standard procedures for sugarcane cultivation.

After the first evaluation, the sugarcane plants were cut and a new inoculation was carried out in the furrows. The inoculants were diluted in water, maintaining the $\mathrm{pH}$ close to the ideal (6.8), and then sprayed on the base of the tillers. A volume of $250 \mathrm{~L}$ of solution with inoculant was used per hectare $\left(10^{9}\right.$ bacteria $\mathrm{mL}^{-1}$ ). After cutting, the ratoon was also fertilized, but without nitrogen.

Plant evaluation was conducted 12 months after planting in the plant-cane (first cycle in 2011) and in the first ratoon (second cycle in 2012). The following traits were evaluated: the number of stalks per plant, average plant length (distance between the first leaf with clearly visible dewlap and the bottom of the stalk, being one stalk per plant), average stalk diameter (average of three stalks per plant measured at the third internode from the bottom), and soluble solids content or Brix (measured on the middle third of the stalk with a field refractometer, using the average of two readings per plant).

The estimation of variance components and prediction of genetic values, named ANADEV, were performed using the REML/BLUP (Residual or Restricted Maximum Likelihood/Best Linear Unbiased Prediction).

The data for all of the evaluated parameters were analyzed using the Selegen REML/BLUP software package(RESENDE, 2006) to determine statistically significant differences between families, bacterial treatments, and interactions between bacteria and plants. This software estimated the components of variance and the prediction of genetic values using the REML/BLUP procedure. The used statistical model is provided below:

$$
\mathrm{y}=\mathrm{Xa}+\mathrm{Zb}+\mathrm{Wp}+\mathrm{Qr}+\mathrm{T}(\mathrm{a} \times \mathrm{b})+\mathrm{e},
$$

where $y$ is the data vector, $a$ is the vector representing the effect of factor A (assumed to be fixed and allocated to the plots) added to general mean; $b$ is the vector of genotypic effect associated with the sub-plot (representing the magnitude of factor $\mathrm{B}$ within the context of factor $\mathrm{A}$, assumed to be random); $p$ is the vector of the plot effect, i.e. the error associated with the interaction of factor A with the factor replications (assumed to be random); $r$ is the vector of the block effect or replications (assumed to be random); $a \times b$ is the vector representing the interaction genotype $\mathrm{x}$ factor $\mathrm{A}$ (assumed to be random); and $e$ is the vector of errors or residuals (assumed to be random). The capital letters (X, Z, $\mathrm{W}, \mathrm{T}$, and $\mathrm{Q}$ ) represent the incidence matrices for the referred effects (RESENDE, 2006).

The correlation between the two cycles was calculated by Pearson's simple correlation between two factors using the software Excel. 


\section{Results and Discussion}

The results of the analysis of deviance for plantcane and first ratoon (Table 2) demonstrated that the chi-square value $\left(\chi^{2}\right)$ between cycles was similar.
The correlation between cycles was 0.87 for the number of stalks, 0.70 for the average length, 0.68 for Brix, and 0.48 for stalk diameter, indicating the repeatability of the results.

Table 2. Results of the analysis of deviance for the parameters number of stalks per plant (NSP), average plant length (APL), average stalk diameter (ASD), and Brix for the 27 families of sugarcane (plant-cane and first ratoon) as a function of the treatment.

\begin{tabular}{lcccccccc}
\hline \multirow{2}{*}{ Effect } & \multicolumn{9}{c}{$\chi^{2}$ values } \\
\cline { 2 - 9 } & \multicolumn{2}{c}{ NSP } & \multicolumn{2}{c}{ APL } & \multicolumn{2}{c}{ ASD } & \multicolumn{2}{c}{ Brix } \\
\cline { 2 - 8 } & Plant & Ratoon & Plant & Ratoon & Plant & Ratoon & Plant & Ratoon \\
\hline Family (F) & $17.10^{* * *}$ & $20.88^{* * *}$ & $9.35^{* * *}$ & $22.34^{* * *}$ & $5.89^{* *}$ & $9.81^{* * *}$ & $12.48^{* * *}$ & $17.47^{* * *}$ \\
Treatment (T) & $0.02 \mathrm{~ns}$ & $0.00 \mathrm{~ns}$ & $88.00^{* * *}$ & $3.28^{*}$ & $164.23^{* * *}$ & $19.16^{* * *}$ & $36.98^{* * *}$ & $22.43^{* * *}$ \\
Block & $0.18 \mathrm{~ns}$ & $2.89 \mathrm{~ns}$ & $35.38^{* * *}$ & $7.48^{* * *}$ & $35.02^{* * *}$ & $6.23^{* *}$ & $12.24^{* * *}$ & $25.83^{* * *}$ \\
Interaction F x T & $0.00 \mathrm{~ns}$ & $0.26 \mathrm{~ns}$ & $0.01 \mathrm{~ns}$ & $1.22 \mathrm{~ns}$ & $1.58 \mathrm{~ns}$ & $2.05 \mathrm{~ns}$ & $6.17^{* *}$ & $18.63^{* * *}$ \\
\hline CV\% & 18.99 & 19.57 & 10.17 & 6.13 & 11.69 & 6.45 & 4.97 & 3.97 \\
\hline Accuracy (rgloc) & 0.99 & 0.94 & 0.98 & 0.90 & 0.92 & 0.84 & 0.79 & 0.71 \\
\hline
\end{tabular}

$* * *$ significant at $1 \%, * *$ significant at $5 \%, *$ significant at $10 \%$, and ${ }^{\mathrm{ns}}$ and not significant.

Pedrozo et al. (2011) found similar results when comparing two cycles of sugarcane crop using tons of stalks per hectare $(T C H)$, tons of Brix per hectare $(T B H)$, and Brix as a parameter. The repeatability was $0.69,0.65$, and 0.38 between cycles for $T C H, T B H$, and Brix, respectively, although the repeatability of Brix was smaller when compared with the present study. According to these authors, the repeatability between two cycles is performed based on the genotype (individual), but the knowledge of the repeatability of families can assist in reducing the time and costs of sugarcane breeding. For these reasons, the present data also imply that the selection at initial stages of sugarcane breeding provides efficient results.

The results of the analysis of deviance also demonstrated significant differences (at 1\% level) for the number of stalks only between families for both cycles.
The traits average stalk length and average stalk diameter showed significant differences between treatments and block. However, the interaction was not significant. For the parameter Brix, significant differences were observed between families, treatment, block, and interaction (family $\mathrm{x}$ treatment) (Table 2).

The average values of the parameters are shown in Table 3. All parameters presented significant differences between treatments for both plant-cane and first ratoon. These results are in accordance with those found by Lopes et al. (2012), who obtained significant values for these traits when comparing families of sugarcane inoculated and not inoculated with Triazo. These authors observed that plants treated with Triazo presented a higher height in relation to untreated plants and non-inoculated plants had higher Brix values in relation to treated plants. 
Table 3. Means of the traits for the 27 sugarcane families according to the used inoculant in cane plant and first ratoon.

\begin{tabular}{lcccccc}
\hline \multirow{2}{*}{ Treatments } & \multicolumn{2}{c}{ Length $(\mathbf{m})$} & \multicolumn{2}{c}{ Diameter $(\mathbf{c m})$} & \multicolumn{2}{c}{ Brix } \\
\cline { 2 - 7 } & \multicolumn{5}{c}{ Mean } \\
\cline { 2 - 7 } & Plant $^{* * * *}$ & Ratoon $^{*}$ & Plant $^{* * * *}$ & Ratoon $^{* * *}$ & Plant $^{* * *}$ & Ratoon $^{* * * *}$ \\
\hline Control & 2.02 & 1.60 & 2.06 & 2.25 & 18.09 & 19.47 \\
Triazo & 2.02 & 1.61 & 2.08 & 2.24 & 17.92 & 19.21 \\
Mix & 2.01 & 1.57 & 2.08 & 2.24 & 18.09 & 19.34 \\
\hline
\end{tabular}

$* * *$ significant at $1 \%, *$ significant at $10 \% \mathrm{e}^{\mathrm{ns}}$ and not significant.

Plants inoculated with Mix were expected to have higher values of stalk height and stalk diameter due to the effect of these bacteria in promoting plant growth. The bacteria that compose Mix have already shown this effect in different experiments, single or in combination, being more suitable for use in the sugarcane crop since they were isolated from stalks and roots of cultivars and hybrids of sugarcane (OLIVEIRA et al., 2009). However, in this study, the results of the inoculant composed by strains of A. brasilense (Triazo) were higher for these traits in relation to Mix (Table 3).

In addition, studies for selecting bacteria that compose the Mix had as main objective to improve BNF (BALDANI; BALDANI, 2005). The other effects in the promotion of plant growth were only recently discovered. In this case, the bacteria of Mix can be considered more effective in BNF since they are endophytic and have a better nitrogenase efficiency when compared to those facultative ( $A$. brasilense) (BASHAN; DUBROVSKY, 1996; MOUTIA et al., 2010). According to Dong et al. (1995), the bacterium G. diazotrophicus can be found in the intercellular spaces of sugarcane stalks, which is a site with a low oxygen availability ideal for a better nitrogenase efficiency.

On the other hand, the species $A$. brasilense is widely known to improve plant growth through different mechanisms. This species is found in different plant species and associated with different types of organisms. Although some authors affirm that the amount of nitrogen fixed by this bacterium is sufficient only for its own consumption, this species presents the highest growth-promoting responses (BASHAN, BASHAN, 2011; MOUTIA et al., 2010; TORTORA et al., 2011).

Figure 1 shows the Brix values for each family according to the different treatments in the plantcane and first ratoon. The Brix value differs as a function of the used treatment, indicating an effect of the interaction family $\mathrm{x}$ inoculant (treatment). The average values of Brix observed in the plantcane were lower when compared to those observed in the first ratoon (Table 3).

Regarding the treatments, some families presented higher Brix values when treated with inoculant, such as the families 2, 4, 9, 10, 11, 13, $19,20,22,23,25$, and 27 in the plant-cane and the families 1, 2, 3, 6, 7, 9, 12, 14, 16, 18, 22, 23, 26, and 27 in the first ratoon. However, the families 1 , $5,12,15$, and 24 presented higher Brix values in the plant-cane when not inoculated, while in the first ratoon, the same results were observed for the families 5, 8, 11, 13, 15, 17, 19, and 24 (Figure 1).

In relation to the average values of Brix, the observed results are similar to those obtained by Pereira (2011), in which the Brix value of the cultivar RB72454 decreased in plants inoculated with Mix (18.05) when compared to those not inoculated (19.4). In our study, plants inoculated with Triazo had lower Brix values. However, for Mix, the values obtained for all the evaluated variables were lower than that found in the control (not inoculated), showing that the response was different between inoculants. 
Figure 1. Genotypic value of Brix of the 27 families of sugarcane for each treatment (non-inoculated, inoculated with Triazo, and inoculated with Mix) in the crop cycles cane plant (A) and first ratoon (B).

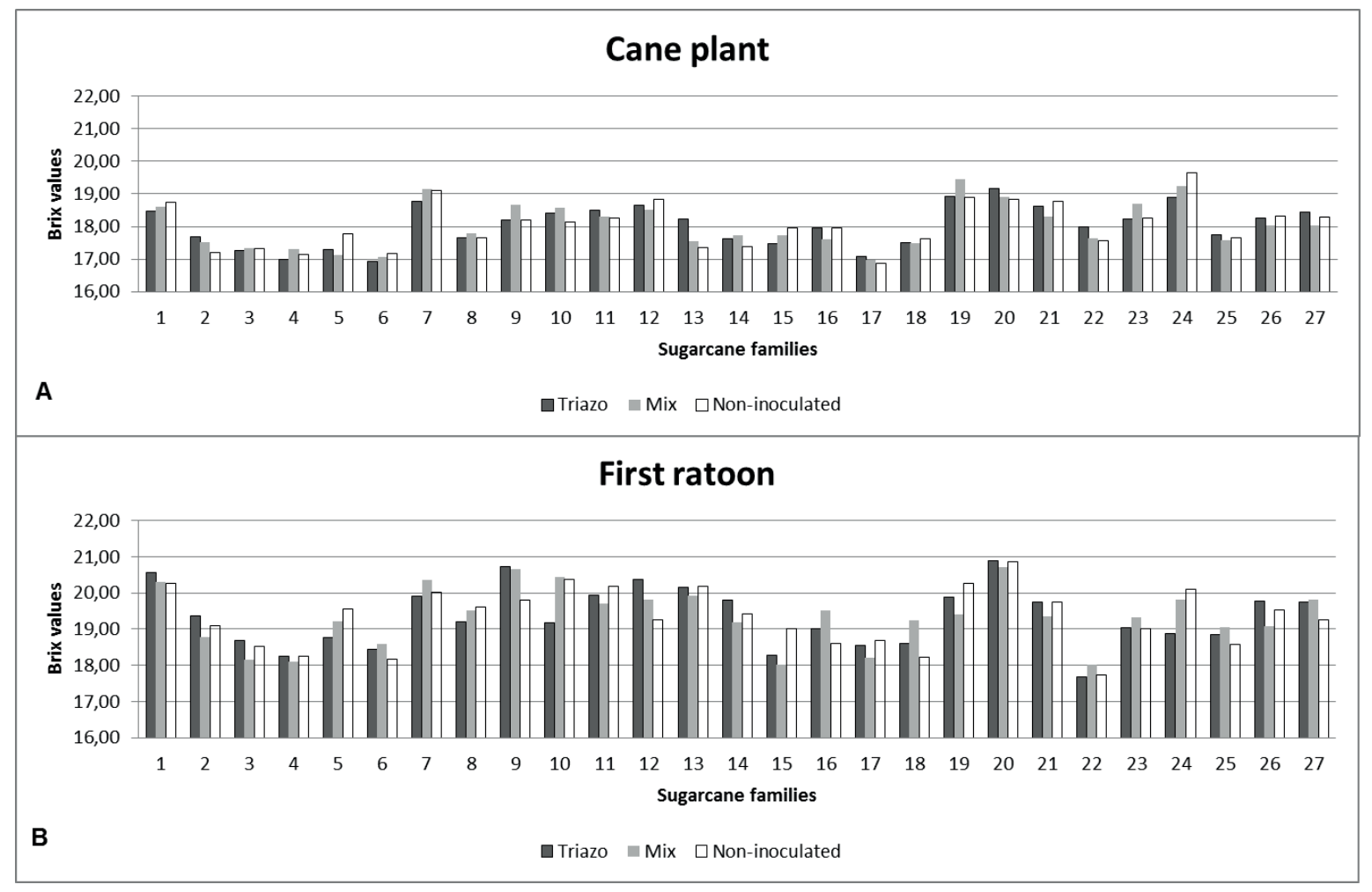

The response to PGPB inoculation, or its efficiency, is related to other environmental factors such as soil type, fertility, moisture, presence of other microorganisms, and organic matter (MOREIRA; SIQUEIRA, 2006). These factors allow diversity in the populations of microorganisms among regions (CABALLERO-MELLADO; MARTINEZROMERO, 1994; TEJERA et al., 2005). Pérez and Casas (2005) isolated different species/strains of Azospirillum from the sugarcane rhizosphere and observed different behaviors for each bacteria, depending on the cultivar and environment of cultivation.

Corroborating these results, Roesch et al. (2007) studied corn samples collected from different regions of Rio Grande do Sul and found a great diversity of diazotrophic endophytic bacteria, especially among communities sampled from different soil types, water regimes, and geographical regions.
According to their results, this variation depends on the evaluated ecosystem, with a regional influence on the population, including soil and climate. Thus, the environmental conditions in the present study may have been more favorable to $A$. brasilense species than to the species that compose the Mix.

However, the interaction values show that the effect of inoculation may be negative or positive depending on the studied family (Figure 2).

The highest values of interaction between families and inoculants for Brix in the plant-cane were observed for the families 19 (0.4503), 9 (0.3364), and 23 (0.3351) when inoculated with Mix and for the families 13 (0.4954), 20 (0.2841), and $22(0.2300)$ when inoculated with Triazo. These positive values indicate that the selection of plants from those families/progenies may be interesting to obtain sugarcane clones with a positive interaction. 
Figure 2. Interaction family $\mathrm{x}$ treatment for Brix of the 27 sugarcane families as a function of the treatment (noninoculated, inoculated with Triazo, and inoculated with Mix) in the crop cycles cane plant (A) and first ratoon (B).
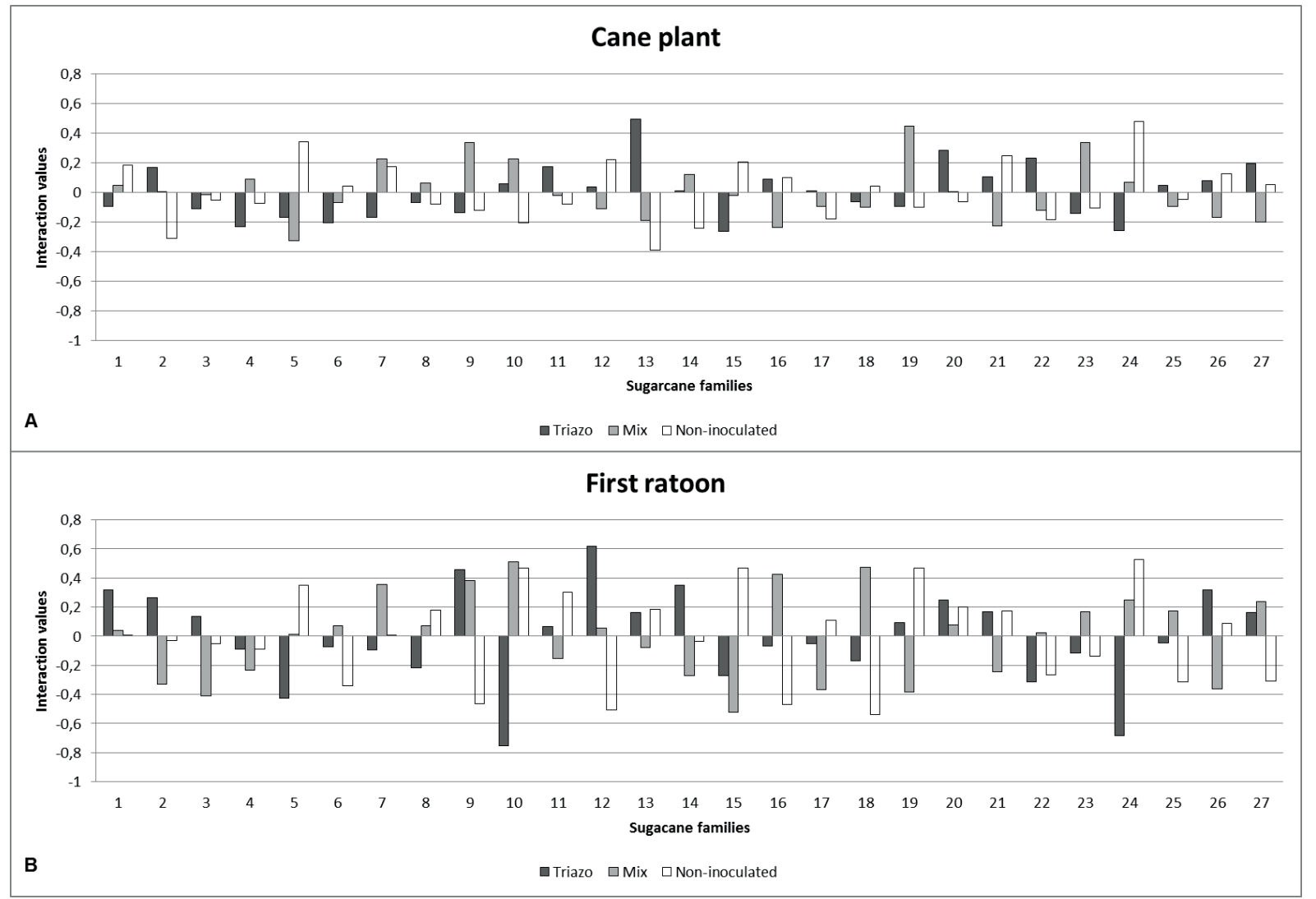

The highest negative values of interaction were observed in the families 4 (-0.2229), 24 (-0.2582), and $15(-0.2608)$ when inoculated with Triazo and in the families $5(-0.3281), 16(-0.2368)$, and 21 $(-0.2245)$ when inoculated with Mix, suggesting that these families may not be interesting for the selection aiming the interaction with these inoculants. One of the most known examples of negative interaction is the sugarcane variety B4362, which is the only that presents the symptoms of Mottled Stripe Disease when inoculated with the species Herbaspirillum rubrisubalbicans (OLIVARES et al., 1997).

Regarding the results obtained in the first ratoon for Brix, the families 10 (0.5137), 18 (0.4718), and $16(0.4273)$ had the highest interaction values when inoculated with Mix, while the families 12 (0.6185), 9 (0.4564), and $14(0.346)$ presented the highest values when inoculated with Triazo. However, the families 10 (-0.7503), 24 (-0.6832), and 5 (-0.4252) presented more negative values when inoculated with Triazo and the families $15(-0.5221), 3$ $(-0.4077)$, and $19(-0.3822)$ when inoculated with Mix (Figure 2).

The families 2, 5, 7, 13, 15, 21, 23, 24, and 26 presented the same behavior for the interaction family $x$ treatment both in the plant-cane and first ratoon although the magnitude of the values was different, indicating the repeatability of the response of these families (Figure 2).

The values of interaction showed the influence of the studied family and evaluated cycle (plantcane and first ratoon), indicating that other factors may have influenced the results. The differences observed between families was also verified by Lopes et al. (2012), who used different inoculants 
composed by $A$. brasilense strains. This plantbacteria interaction has been mentioned by several authors and might be positive or negative depending on the plant genotype and the species and/or bacterial strain (OLIVARES et al., 1997; MUÑOZ-ROJAS; CABALLERO-MELLADO, 2003; OLIVEIRA et al., 2006; PEREIRA, 2011).

The different values observed for Brix in the plantbacterial interaction also denote that the selection of plants in this initial stage, without nitrogen fertilization, could be an alternative for selecting clones aiming at the best association with PGPB. In the case of soybean cultivars, the breeding on soils with a low nitrogen content, without fertilization and with inoculation with Bradyrhizobium, favored the interaction between plant and bacteria, promoting high productivity indices of this crop (ALVES et al., 2003; ALCANTARA et al. 2009). In addition, the Brix is one of the main evaluated traits in this stage of selection, defining whether a genotype is selected, in addition to visual traits (height, number of stalks, diameter, and disease resistance) (MATSUOKA et al., 2005).

Under these conditions, with a significant effect for the interaction family $\mathrm{x}$ inoculant, the inoculation of all plants would favor those with a significant and positive interaction and would adversely affect those with a negative interaction. However, the selection of native bacteria with a better adaptation to the cultivation environment could also favor the results of sugarcane cultivation, as the results obtained for soybean breeding (ALVES et al., 2003).

\section{Conclusion}

The 27 families of sugarcane presented a positive and negative response to inoculation with nitrogenfixing bacteria and growth-promoting bacteria. The response varied depending on the studied family, used inoculant, and the evaluated characteristics. Brix was the only variable that showed a significant interaction between plant and bacteria. The families
$2,5,7,13,15,21,23,24$, and 26 presented similar values for both cycles (plant-cane and first ratoon). The results showed that the inoculation is possible in the early breeding stages and that plants with a positive interaction may be identified even in the early breeding stages.

\section{References}

ALCANTARA, R. M. C. M.; ROCHA, M. M.; XAVIER, G. R.; RUMJANEK, N. G. Estado atual da arte quanto à seleção e o melhoramento de genótipos para a otimização da FBN. Teresina. Empresa Brasileira de Pesquisa Agropecuária, EMBRAPA Meio-Norte, 2009. 31 p. (Documento, 196).

ALVES, B. J. R.; BODDEY, R. M.; URQUIAGA, S. The success of BNF in soybean in Brazil. Plant and Soil, The Hague, v. 252, n. 1, p. 1-9, 2003.

ARZANESH, M. H.; ALIKHANI, H. A.; KHAVAZI, K.; RAHIMIAN, H. A.; MIRANSARI, M. In vitro growth of wheat (Triticum aestivum L.) seedlings, inoculated with Azospirillum sp. under drought stress. International Journal of Botany. Cairo, v. 5, n. 3, p. 244-249, 2009.

BALDANI, I. J.; BALDANI, L. V. History on the biological nitrogen fixation research in graminaceous plants: special emphasis on the Brazilian experience. Anais da Academia Brasileira de Ciências, Rio de Janeiro, v. 77, n. 3, p. 549-579, 2005.

BASHAN, Y.; BASHAN, L. E. How the plant growthpromoting bacterium Azospirillum promotes plant growth: a critical assessment. Advances in Agronomy, London, v. 108, n. 1, p. 77-136, 2011.

BASHAN, Y.; DUBROVSKY, J. G. Azospirillum spp. participation in dry matter partitioning in grasses at the whole plant level. Biology and Fertility of Soils, Firenze, v. 23 , n. 4, p. 435-440, 1996.

BASHAN, Y.; HARRISON, K.; WHITMOYER, R. Enhanced growth of wheat and soybean plants inoculated with Azospirillum brasilense is not necessarily due to general enhancement of mineral uptake. Applied and Environmental Microbiology, Washington, v. 56, n. 3, p. 769-775, 1990.

CABALLERO-MELLADO, J.; MARTINEZ-ROMERO, E. Limited genetic diversity in the endophytic sugarcane bacterium Acetobacter diazotrophicus. Applied and Environmental Microbiology, Washington, v. 60, n. 5, p. 1532-1537, 1994. 
COELHO, C. H. M.; MEDEIROS, A. F. A.; POLIDORO, J. C.; XAVIER, R. P.; RESENDE, A.; QUESADA, D. M.; ALVES, B. J. R.; BODDEY, R.; URQUIAGA, S. Identification of genotypes of sugar cane with respect to their potential contribution from biological nitrogen fixation. Agronomia, Garça, v. 37, n. 2, p. 37-40, 2003.

DONG, Z.; HEYDRICH, M.; BERNARD, K; MCCULLY, M. E. Further evidence that the N 2 fixing endophytic bacterium from the intercellular spaces of sugarcane stems is Acetobacter diazotrophicus. Applied and Environmental Microbiology, v. 61, n. 5, p. 18431846, 1995.

EMPRESA BRASILEIRA DE PESQUISA AGROPECUARIA - EMBRAPA. Sistema Brasileiro de classificação de solos. Brasília: Embrapa Informação Tecnológica, 1999. 412 p.

FOOD AND AGRICULTURE ORGANIZATION OF THE UNITED NATIONS - FAO. World reference base for soil resources. Rome: Food and Agriculture Organization, 2006. 145 p.

HARI, K.; SRINIVASAN, T. R. Response of sugarcane varieties to application of nitrogen fixing bacteria under different nitrogen levels. Sugar Tech, Lucknow, v. 7, n. 2-3, p. 28-31, 2005.

HUNGRIA, M.; CAMPO, R. J.; SOUZA, E. M.; PEDROSA, F. O. Inoculation with selected strains of Azospirillum brasilense and A. lipoferum improves yields of maize and wheat in Brazil. Plant and Soil, The Hague, v. 331, n. 1-2, p. 413-425, 2010.

INSTITUTO AGRONÔMICO DO PARANÁ - IAPAR. Cartas Climáticas do Estado do Paraná. Londrina: Instituto Agronômico do Paraná, 1994. 49 p.

LOPES, V. R.; BESPALHOK-FILHO, J. C.; ARAUJO, L.; RODRIGUES, F. V.; DAROS, E.; OLIVEIRA, R. A. The selection of sugarcane families that display better associations with plant growth promoting rhizobacteria. Journal of Agronomy, Punjab, v. 11, n. 2, p. 43-52, 2012.

MARIN, V. A.; BALDANI, V. L.; TEIXEIRA, K. R. S.; BALDANI, J. I. Fixação biológica de nitrogênio: bactérias fixadoras de nitrogênio e sua importância para a agricultura tropical. Seropédica: EMBRAPA-CNPAB, 1999. 24 p. Disponível em: <http://www.cnpab.embrapa. br/publicacoes/fbn_nao_leg.html $>$. Acesso em: 12 nov. 2010 .

MATSUOKA, S.; GARCIA, A. A. F.; ARIZONO, H. Melhoramento da cana-de-açúcar. In: BOREM, A. Melhoramento de espécies cultivadas. Viçosa, MG: Editora UFV, 2005. p. 205-251.
MOREIRA, F. M. S.; SIQUEIRA, J. O. Microbiologia e bioquímica do solo. 2. ed. Viçosa: Editora UFLA, 2006. $729 \mathrm{p}$.

MOUTIA, J. F. Y.; SAUMTALLY, S.; SPAEPEN, S.; VANDERLEYDEN, J. Plant growth promotion by Azospirillum sp. in sugarcane is influenced by genotype and drought stress. Plant and Soil, The Hague, v. 337, n. 1-2, p. 233-242, 2010.

MUÑOZ-ROJAS, J.; CABALLERO-MELLADO, J. Population dynamics of Gluconacetobacter diazotrophicus in sugarcane cultivars and effect on plant grow. Microbial Ecology, Rockville, v. 45, n. 4, p. 454464, 2003.

OLIVARES, F. L.; JAMES, E. K.; BALDANI, J. I.; DOBEREINER, J. Infection of mottled stripe diseasesusceptible and resistant sugar cane varieties by the endophytic diazotrophyc Herbaspirilium. New Phytologist, Lancaster, v. 135, n. 4, p. 723-737, 1997.

OLIVEIRA, A. L. M.; CANUTO, E. L.; URQUIAGA, S.; REIS, V. M.; BALDANI, J. I. Yield of micropropagated sugarcane varieties in different soil types following inoculation with diazotrophic bacteria. Plant and Soil, The Hague, v. 284, n. 1-2, p. 23-32, 2006.

OLIVEIRA, A. L. M.; STOFFELS, M.; SCHMID, M.; REIS, V. M.; BALDANI, J. I.; HARTMANN, A. Colonization of sugarcane plantlets by Mixed inoculations with diazotrophic bacteria. European Journal of Soil Biology, Braunschweig, v. 4, n. 5, p. 106-113, 2009.

PEDROZO, C. A.; BARBOSA, M. H. P.; SILVA, F. L.; RESENDE, M. D. V.; PETERNELLI, L. A. Repeatability of full-sib sugarcane families across harvests and the efficiency of early selection. Euphytica, Dordrecht, v. 182, n. 3, p. 423-430, 2011.

PEREIRA, W. Produtividade e qualidade tecnológica da cana-de-açúcar inoculada com bactérias diazotróficas. 2011. Dissertação (Mestrado em Agronomia) Universidade Federal Rural do Rio de Janeiro, Seropédica.

PÉREZ, J.; CASAS, M. Efecto de la interacción planta-Azospirillum en el cultivo de la caña de azúcar (Saccharum sp). Cultivos Tropicales, La Habana, v. 26, n. 4, p.13-19, 2005.

RESENDE, M. D. V. de. O software selegen-Reml/Blup. Campo Grande: EMBRAPA Informação Tecnológica, 2006. 67 p.

ROESCH, L. F. W.; PASSAGLIA, L. M. P.; BENTO, F. M.; TRIPLETT, E. W.; CAMARGO, F. A. O. Diversidade de bactérias diazotróficas endofíticas associadas a plantas de milho. Revista Brasileira de Ciência do Solo, Viçosa, MG, v. 31, n. 6, p. 1367-1380, 2007. 
TEJERA, N.; LLUCH, C.; MARTÍNEZ-TOLEDO, M. V.; GONZÁLEZ-LOPEZ, G. Isolation and characterization of Azotobacter and Azospirillum strains from the sugarcane rhizosphere. Plant and Soil, The Hague, v. 270, n. 1, p. 223-232, 2005.

TORTORA, M. L.; DIAZ-RICCI, J. C.; PEDRAZA, R. O. Azospirillum brasilense siderophores with antifungal activity against Colletotrichum acutatum. Archives of Microbiology, Braunschweig, v. 193, n. 4, p. 275-286, 2011.
URQUIAGA，S.; CRUZ，K. S.; BODDEY，R. M. Contribution of nitrogen fixation to sugar cane: Nitrogen-15 and nitrogen-balance estimates. Soil Science Society of America Journal, Madison, v. 56, n. 1, p. 105114, 1992.

VERMA, J. P.; YADAV, J.; TIWARI, K. N.; LAVAKUSH SINGH, V. Impact of plant growth promoting rhizobacteria on crop production. International Journal of Agricultural Research, v. 5, n. 11, p. 954-983, 2010. 
